\title{
LEXICON
}

\section{APOLOGY STRATEGY USED BY THE CHARACTERS IN FOUR CARTOON MOVIES}

\author{
Devy Putri Larasati
}

\begin{abstract}
This article discusses apology expressions in four cartoon movies. The goals are to describe the strategy of apology and explain how the utterances of apologies are affected by familiarity.

The research collected the data from dialogues that consist of apology in Monsters University, Frozen, Mulan, and Mulan II. In analyzing the data, it followed five steps: (1) finding and understanding the context of the utterances of the apology expression in order to understand the speaker's utterances; (2) identifying and describing the utterances based on the category of apology strategy; (3) analyzing the data based on the theory of apology strategy by Olshtain \& Cohen; (4) analyzing the use of apology influence by familiarity; (5) making conclusion based on the results of the data analysis.

The results show that two apology strategies, an expression of an apology and an explanation or account of the situation, dominate the ranks. They are then followed by an acknowledgment of responsibility, and an offer of repair, and a promise of forbearance. Meanwhile, the relation between the speakers also influence the use of apology.
\end{abstract}

Keywords: cartoon movies, utterances, apology strategy, familiarity, pragmatics

\section{INTISARI}

Penelitian deskriptif ini membahas ekspresi permintaan maaf pada empat film kartun. Tujuan penelitian ini adalah mendeskripsikan strategi permintaan maaf dan menjelaskan pengaruh faktor hubungan keakraban terhadap ucapan permintaan maaf.

Data penelitian diambil dari dialog yang berisikan ekspresi permintaan maaf pada film kartun berjudul Monsters University, Frozen, Mulan, dan Mulan II. Analisis data menempuh lima tahap: (1) menemukan dan memahami konteks ucapan-ucapan ekspresi permintaan maaf untuk mengetahui apa maksud penutur; (2) mengidentifikasi dan mendeskripsikan ucapan berdasarkan kategori strategi permintaan maaf; (3) menganalisis data menggunakan teori strategi permintaan maaf oleh Olshtain \& Cohen; (4) menganalisis strategi permintaan maaf yang dipengaruhi oleh hubungan keakraban; (5) membuat kesimpulan berdasarkan hasil analisis data. 
Hasil penelitian ini menunjukkan bahwa dua strategi permintaan maaf yang mendominasi yaitu ekspresi permintaan maaf dan penjelasan terhadap situasi. Hal ini kemudian diikuti dengan pengakuan pertanggungjawaban, tawaran untuk perbaikan, dan janji tidak akan mengulangi. Sementara itu, keakraban antara penutur juga mempengaruhi penggunaan permintaan maaf.

Kata kunci: film kartun, ucapan, strategi permintaan maaf, keakraban, pragmatik 


\section{INTRODUCTION}

People use language for various reasons. Usually, they use it to express their ideas, desires, thoughts, knowledges, and feelings. It can even be used to maintain social relationship. Finnegan, et al claims that language is principally a tool for doing things (3). For example, people use language to express apologies that is to tell someone that they are sorry for having done something that has caused $\mathrm{him} / \mathrm{her}$ inconvenience or unhappiness.

Apology is a speech act used to restore relationship between a speaker $(\mathrm{S})$ and hearer $(\mathrm{H})$ after $\mathrm{S}$ has offended $\mathrm{H}$ intentionally or unintentionally (Olshtain \& Cohen 21). In other words, this speech act requires the presence of two participants, namely the person who is apologizing and the person who expects an apology. The speaker here requires an action or an utterance to set things right and maintain or restore harmony.

In fact, some people feel awkward and confused to admit and apologize for the mistakes they have done. They just simply say, "I'm sorry", but sometimes it is not enough for the person who expects an apology. They want something more from the person who is apologizing. Because of this, people should know about apology strategy which shows the methods used by individuals to perform the speech act of apology such as statement of remorse and reparation in order to avoid misunderstanding and miscommunication which can hurt others.

The writer is interested in doing a research on apology because the use of apology in daily lives is very commonly found. People make mistakes but they must have the willingness to admit and apologize for the mistakes they have made, for example, a man apologizes for accidentally breaking someone's camera or apologizes because of a more severe situation like missing a meeting with an important person. Here, the correct use of apology has an important role in order to get a meaningful and clear communication. Basically, an apology does not always contain verbs such as "sorry", "excuse", "forgive”, or "apologize". Sometimes people convey their apology through actions or words which indirectly contain the expression of apology. Moreover, in terms of Sociolinguistics, it is also known that there are differences in using language based on factors like gender, age, relationship, ethnicity, religion, status, level of education, and others.

This research aims to find out apology strategy used in the cartoon movies entitled Frozen, Monsters University, Mulan, and Mulan II and to analyze how familiarity affects the use of apology.

In the method of collecting the data, the researcher applied several procedures. First of all, the researcher watched Frozen, Monsters University, Mulan, and Mulan II which were downloaded from the internet. The movies came with English subtitle. While watching each movie, the researcher focused on the apology utterances made by the characters. When the data were found, the researcher paused the movie, wrote the dialogue containing the apology expression uttered by the characters, and noted the time marker. The time marker was written when the dialogue started. The process of collecting the data took a week.

The data obtained from the characters' utterances in Frozen, Monsters University, Mulan, and Mulan II were analyzed using the theory of apology strategy by Olshtain and Cohen. The main purpose of the analysis was to find out which kinds of apology strategy were used by the characters of Frozen, Monsters University, Mulan, and Mulan II and to find how familiarity influence the use of apology. The steps to analyze the data include:

- First, finding and understanding the context of apology utterances used by the characters in Frozen, Monsters University, Mulan, and Mulan II.

- Second, identifying and describing the utterance based on the category of apology strategy.

- Third, analyzing and categorizing the data using the theory of apology strategy proposed by Olshtain and Cohen. Those categories include an expression of apology, an expression of responsibility, an explanation or account of the 
situation, an offer of repair, and a promise of forbearance.

- Fourth, analyzing the use of apology influenced by familiarity using Fraser's theory.

- Fifth, drawing conclusions based on the results of the data analysis.

The following part discusses the kinds of apology strategy used in the cartoon movies entitled Frozen, Monsters University, Mulan, and Mulan II based on the theory of apology strategy proposed by Olshtain and Cohen and analyze how familiarity affects the use of apology by using Fraser's theory.

\section{DISCUSSION}

This part discusses the kinds of apology found in the cartoon movies entitled Frozen, Monsters University, Mulan, and Mulan II. It also presents the results of the data analysis by emphasizing on the classification of apology strategies. There are 37 apology utterances which are taken from four cartoon movies entitled Frozen (F), Monsters University (MU), Mulan (M), and Mulan II (MII).

\subsection{Apology Strategy}

Table 1. Apology strategy used by the characters in Frozen (F), Monsters University (MU), Mulan (M), and Mulan II (MII) based on Olshtain's and Cohen's theory.

\begin{tabular}{|c|l|c|c|c|c|c|c|}
\hline No. & \multicolumn{1}{|c|}{ Apology Strategy } & MU & F & M & MII & Total & Percentage \\
\hline 1 & $\begin{array}{l}\text { An expression of an } \\
\text { apology (IFID) }\end{array}$ & 7 & 4 & 0 & 1 & 12 & $32 \%$ \\
\hline 2 & $\begin{array}{l}\text { An explanation or } \\
\text { account of the situation } \\
\text { (EXPL) }\end{array}$ & 7 & 2 & 4 & 4 & 17 & $46 \%$ \\
\hline 3 & $\begin{array}{l}\text { An acknowledgmentof } \\
\text { responsibility (RESP) }\end{array}$ & 1 & 3 & 0 & 0 & 4 & $11 \%$ \\
\hline 4 & $\begin{array}{l}\text { An offer of repair } \\
\text { (REPR) }\end{array}$ & 0 & 1 & 0 & 2 & 3 & $8 \%$ \\
\hline 5 & $\begin{array}{l}\text { A promise of } \\
\text { forbearance (FORB) }\end{array}$ & 1 & 0 & 0 & 0 & 1 & $3 \%$ \\
\hline & TOTAL & 16 & 10 & 4 & 7 & 37 & $100 \%$ \\
\hline
\end{tabular}

In summary, the most frequent strategies used are explanation or account of the situation, which confirms Olshtain and Cohen's findings that only single strategy is enough in apology across situations (25). Meanwhile, another strategy mostly used is an expresssion of apology with the expression I'm sorry.

\subsubsection{An Expression of an Apology}

This strategyis used when someone regrets what he/she has done. An expression of apology is considered as direct apology. The speaker uses a word, expression, or sentence containing a word such as "sorry", "excuse", "forgive" or "apologize". (Olshtain \& Cohen 22)

In Monsters University, Frozen, Mulan, and Mulan II, there are 12 expressions of apology: 7 examples can be found in Monsters University, 4 examples in Frozen, and 1 other example in Mulan II. However, this article does not discuss all of the expressions of apology but only provides several examples. 


\section{Example 1 (taken from Monsters University)}

[Mike, a new student in Monsters University is looking for his room in the boarding school. He is very anxious to meet his roommate who is also taking the scaring program. After some time, he finally finds his room and knocks the door which is opened by Randy Boggs, a monster resembling lizard. Mike is shocked. He thinks that Randy is a scary monster, but actually he is very kind].

Randy Boggs : Hey there, I'm your roommate. Name's Randy Boggs, scaring major. [Shaking hands as an introduction]

Mike : Mike Wasowski, scaring major.

Randy Boggs : I can tell we're gonna be best chums, Mike! Take which ever bed you want. I wanted you to have first dibs. [Suddenly he disappeared]

Mike : You just disappeared! [Surprised]

Randy Boggs : [Suddenly he appeared]. Sorry. [Take a long time to continue his words]. IfI do that in scaring class, I'll be a joke.

Mike : No, it's totally great. You gotta use it.

This conversation happens when Mike meets his new roommate for the first time. They introduce themselves. Randy, a student of scaring program tries to show his special ability to Mike, his new friend. When Randy finishes his introduction, he suddenly disappears. Mike is very shocked with his friend's disappearance. When Randy sees Mike's shocked expression, he feels guilty. He expresses his apology by saying, "Sorry". He uses it as a direct apology. In addition, according to the severity of the infraction, the mistake which is made is not so serious because it does not cause any accident or damage. Besides, Randy only says sorry without any complex structure of apologizing and any further explanation about what had happened.

\section{Example 2 (taken from Frozen)}

[Kristoff is an ice cube seller. He stops by in a shop to buy carrots for his donkey. He has an argument with the shop owner because he is asked to pay $\$ 40$ for the carrots. He tells the shop owner that he does not have enough money and he should go to the North Mountain as soon as possible. By chance, Anna is listening to their conversation. This is good luck for her because she wants to go to the North Mountain to look for Elsa. Because they do not come to an agreement on the price, finally Kristoff leaves the shop and buys nothing. Kristoff and the donkey spend the night in a hut]. Kristoff : [Singing a song with his donkey]

Anna : [Suddenly comes]. Nice duet.

Kristoff : [Gasps]. [Sighs]. It is just you. What do you want?

Anna : I want you to take me up to the North Mountain.

Kristoff : I don't take people places.

Anna : Let me rephrase that. [Throws a bag to Kristoff]

Kristoff : [Groans]. Hey.

Anna : Take me up to the North Mountain. Please.

Kristoff : [Opens the bag containing rope and ice pick]

Anna : Look, I know how to stop this winter.

Kristoff : We leave at dawn. And you forgot the carrots for Sven.

Anna : [Throws a bag of carrots]

Kristoff : [Grunts]

Anna : Ooops, sorry. I'm sorry. I'm sorry. I didn't ... [Clearing her throat]. We leave now. Right now.

This conversation happens after Kristoff leaves the shop and finds a hut to spend the night before going to the North Mountain at dawn. Fortunately, he finds a small hut near the shop. Inside the hut, Kristoff and his donkey sing a song. Meanwhile, in the shop, Anna is still thinking about how to go to the North Mountain to meet her sister. Finally, she decides to ask Kristoff to take her there. She buys 
him rope, ice pick, and carrots for the donkey. When Kristoff and Sven are singing, Anna enters the hut and praises their duet. Then, she asks Kristoff to take her to the North Mountain. He initially refuses but Anna throws him a bag containing rope and ice pick. Kristoff agrees to take her to the North Mountain, but he wants to leave at dawn. Because he is so annoying, Anna throws him a sack of carrots for his donkey. It makes him hurt. When she sees Kristoff's expression, Anna realizes that she has offended him. Then, Anna apologizes for her mistake by saying "I'm sorry". She uses it as a direct apology. Whereas, she wants to continue her words of apologizing but she also chooses to keep her prestige. So, she only says, "Ooops, sorry. I'm sorry. I'm sorry", without any complex structure of apologizing and any further explanation about what had happened. It is a common and simple apology.

\subsubsection{An Explanation or Account of the Situation}

This is a strategy in which the speaker tells what has happened. $\mathrm{He} /$ she describes the situation which causes him/her to do the offense. For example when a person is late for a meeting, he/she will say, "I'm sorry, there was a traffic jam”. (Olshtain \& Cohen 22)

The results show that an explanation or account of the situation is the most frequently used strategy. There are 17 examples: 7 examples can be found in Monsters University, 2 examples in Frozen, 4 examples in Mulan, and 4 other examples in Mulan II. However, in this paper, the researcher provides 2 examples.

\section{Example 3 (taken from Monsters University)}

[Mike and his team, OK Team joins a scaring competition. It is a group competition where every member should do a scary simulation in order to get a score. The teacher prepares some properties like a doll as a miniature of a baby and parameters to find out how scary the participants are. In their team, Mike is the last contestant who does the simulation. Unexpectedly, he gets maximum point which makes their team become the winner of that competition. This means that they do not have to leave Monsters University. All the members of OK Team stand in the middle of the yard except Mike who is standing near the props]

Sullivan : You guys killed it out there! [Talking to their team].

Hey, Wazowski! Come on, let's go, you maniac! We're celebrating. [Sullivan approaches Mike]. Mike?

Mike : I did it. I can't believe it. I'm gonna be a scarier!

Sullivan : Yes, yes, you are!

Mike : [Started talking to the doll which was used as a prop in the scaring competition]. Hey, you hear that? Get plenty of rest, kiddo. You haven't seen the last of Mike Wazowski. [He started to scare the doll again. The doll screams and jumps]. [Mike is still wondering why this could happen].

Mike : I know I was scary, I didn't know I was that scary. [He talks to the doll].

Sullivan : Yeah, we're so scary I guess we broke it, come on!

Mike : [He touches the doll. The doll screams and jumps meaning that it is afraid. Mike finds something wrong with the prop]. It has been tampered with.

Sullivan : Oh, I don't think you should be messing with that.

Mike : Why are my settings different?

Sullivan : Mike, we should leave.

Mike : Did you do this?

Sullivan : Mike...

Mike : Did you do this?

Sullivan : Yes, I did. Sorry, but ... you don't understand.

Mike : Why? Why did you do this?

Sullivan : You know, just in case...

Mike : In case of what? You don't think I'm scary.

Sullivan : Mike...

Mike : You said you believed in me. But you're just like Hardscrabble, you're just like everyone else! 
Sullivan : Look, you'll get better and better... Mike : I'm as scary as you! I'm as scary as anyone else.

Sullivan : I'm sorry, I just wanted to help you.

Mike : No, you just wanted to help yourself.

This conversation happens when OK Team has just finished their scaring competition and is announced as the winner of the competition. The other contestants are getting ready to leave, except OK Team, who wants to celebrate their victory. Mike stands near the prop which is used in the competition. He does not think that he was that scary to get the maximum point in the competition. Sullivan then tries to convince Mike that he deserves to get the maximum point and persuades him to leave the prop. Mike refuses to leave because he knows that there is something wrong with it. Sullivan panics because he is afraid that Mike will know that he is the one who tampered with the prop. However, with great curiosity, Mike tries to find out the oddities in the prop. Until he finds that the setting for him is set differently from the others.

Mike has already guessed that Sullivan is the one who set the props for him, but when Mike asks him about it, Sullivan is unable to give an explanation. Mike makes Sullivan realize that he has made a mistake. Then, Sullivan apologizes for lying and underestimating Mike. Thus, he expresses his apology by saying "I'm sorry" followed by an explanation. He explains why he does the mistake. Sullivan says that he wants to help Mike to get the maximum score in the competition. He explains it in order to make Mike understand that he does it for good. He does not want Mike to get a bad score in the competition. If it happens, Mike and all the member of OK Team should leave Monsters University.

\subsubsection{An Acknowledgment of Responsibility}

This is a strategy of apologizing in which the speaker tries to describe his/her faults in causing the violation. The speakers takes responsibility by overtly admitting that the situation is his or her fault, for example "... at that time I did not have that amount of money, I was confused, I did not see you", "I did not mean it", "I didn't do it on purpose”. (Olshtain \& Cohen 23)

\section{Example 4 (taken from Monsters University)}

[It is in the middle of the night. Finally, Mike knows that Sullivan is the one who sets up the parameters which is used by Mike in the scaring competition. So, he decides to go to the pond to relax himself. But accidentally, Sullivan sees Mike and approaches him].

Sullivan : Mike! Come on, buddy, let's get you outta here.

Mike : [No reaction. Mike is silent while looking at the pond]

Sullivan : [Takes a deep breath]. This is all my fault.

Mike : You were right. They weren't scared ofme.

This conversation shows that Mike is a little bit disappointed and angry with Sullivan. Thus, Sullivan apologizes and admits that it is all his mistake. Sullivan is the one who should take the responsibility of his fault. He has changed the parameters and he also lies to Mike. All this makes Mike angry with him. As a matter of fact, Sullivan does not mean to lie to Mike. He just wants to help Mike and his team to win the competition, so that they do not have to leave Monsters University.

\section{Example 5 (taken from Frozen)}

[Coronation Day is approaching. Many people come to see the new queen and princess. After all the preparations, Elsa asks her maids to open the gate. This is the first time for Anna to go outside the castle. She sings and dances while walking along the courtyard. But something happens to her].

Anna : Hey! [Shocked]

Prince Hans : Are you hurt?

Anna : Hey. [Chuckles nervously] Uh. [Stutters]. No, no, I'm okay.

Prince Hans : Are you sure? 
Anna

: Yeah, I just wasn't looking where I was going. But, I'm great, actually.

Prince Hans : Oh... Thank goodness. [Giving his hand to Anna].

Oh, uh... Prince Hans of Southern Isles.

Anna : Princess Anna of Arendelle.

Prince Hans : Princess? My lady. [Bowing his body].

Anna : :Uh... [Confused]

Prince Hans : I'd like to formally apologize for hitting the princess of Arendelle with my horse. And for every moment after.

Anna : No! No, no. It's fine. I'm not that princess.

Anna is hit by a prince on a horse. She is almost angry but when she sees his face, she decides not to be angry. Anna becomes nervous because of his appearance. He is handsome, charming, and charismatic. This accident leads them into a short introduction. Apparently, Prince Hans does not know that the woman he hit is the princess ofArendelle. After realizing that she is a princess, he uses formal language. Thus, Prince Hans is the one who should take the responsibility for his mistake. He is sorry for hitting the princess with his horse. Meanwhile, the severity of the infraction is serious because that accident makes Princess Anna fall down. It also can be seen from the apology strategy which is used by the prince. He does not only say "I'm sorry" but also explains what he did before and for every moment after.

\subsubsection{An Offer of Repair}

This is a strategy in which the speaker tries to repair the damage, he/she has incurred on others and offers words that may cause the harm done to be forgotten. He/she makes a bid to carry out an action or provide payment for some kind of damage resulting from his/her fault. An offer of repair would be relevant only if physical injury or other damages have resulted for example, "I will pay for the broken vase" or "I will help you get up". (Olshtain \& Cohen 23)

\section{Example 6 (taken from Mulan II)}

[The sisters have tea around the camp fire near the tent. Mei admires Yao who is carving the wood while Ting-ting and Su are in conversation. Lingling suddenly comes over to Ting-ting].

Ling-ling : Excuse me, Your Highness. I found your fan. It just needed a little drying out. [Gives the fan to her].

Ting-ting : Thank you, Ling. [Takes the fan].

Ling-ling : Normally, I would say, 'I'm your biggest fan”. But ... I'll just go away now, again. [Goes away from the camp fire while watching Ting-ting]. [Suddenly, he hits the fireplace].

Sorry, I'll replace that.

Ling-ling comes over to Ting-ting to give back her missing fan. Actually, Ling-ling is in love with Tingting, but he does not dare to express it. Ling-ling uses this opportunity to get close to Ting-ting. He says that he is Ting-ting's biggest fan. But, Ting-ting does not respond to this statement. It makes Lingling sad and nervous. Then, Ling-ling leaves the camp fire but he does not mind his step. He hits the fireplace and breaks the cauldron. He is guilty of his action. He makes a bid to carry out an action for some kind of damage resulting from his fault. Thus, in order to makes amends, he says that he will replace the fireplace and the cauldron for the sisters.

\subsubsection{A Promise of Forbearance}

This is a strategy used when the speaker does his/her utmost to assure the injured party that whatever has taken place will not occur again in the future. While a promise of forbearance relates to a case where the speaker could have avoided the offense but did not do so, perhaps repeatedly, for example when someone has forgotten an appointment with a friend more than once, the person might want to say something. He/she commits his/herself to not repeat the offense, for example, "This time I promise not to do it again". (Olshtain \& Cohen 23) 
In Monsters University, there is only one utterance that shows a promise of forbearance and none is found in Frozen, Mulan, and Mulan II.

\section{Example 7 (taken from Monsters University)}

[It is afternoon in the area of scaring competition. All the contestants get together to prepare for the competition on the next day. There is also Dean Hardscrabble who monitors her students 'preparation to join the scaring competition. She is walking around the yard and Sullivan, a member of OK Team, sees her].

Sullivan

$$
\begin{aligned}
& \text { : Dean Hardscrabble! If we get } \\
& \text { back into the scaring program, } \\
& \text { I promise not to make } \\
& \text { mistakes anymore. }
\end{aligned}
$$

Dean Hardscrabble : [Started to leave]. Tomorrow each of you must prove that you're undeniably scary. And I know for a fact that one of you is not.

Before that conversation happens, Sullivan and Mike are dropped out by Dean Hardscrabble from the scaring program. It happens because both of them have broken Dean Hardscrabble's souvenir. But the next day, Dean Hardscrabble gives them a challenge to join the group competition. She said that if they win she will let the entire team into the scaring program. If they lose, they should leave Monsters University. Sullivan hopes that both of them could get back into the scaring program. He realizes his mistake of breaking Hardscrabble's souvenir. $\mathrm{He}$ also commits himself not to repeat the offense. $\mathrm{He}$ said, "I promise not to make mistakes anymore". Sullivan really means it but Dean Hardscrabble does not want to listen to his explanation.

\subsection{The Influence of Familiarity on the Use of Apology}

This following section discusses how the factor like relative influences the use of apology. Fraser points out five factors that influence the choice of strategy of apology namely the nature of infraction, the severity of infraction, the situation in which the infraction occurs, the relative familiarity between the interactant and the sex of the interactant (263). But here, the researcher based the research on relative familiarity between the interactant.

The relative familiarity of the interactant refers to how the relationship between the speaker and the offended, whether they have a close relationship or distant relationship and whether they are close friends or not. It is possible to choose different words of apology (268).

Table 2. The choice of apology words based on familiarity in Frozen, Monsters University, Mulan, and Mulan II.

\begin{tabular}{|c|c|c|}
\hline No. & Unfamiliar & Familiar \\
\hline 1 & Pardon & Sorry \\
\hline 2 & I'd like to formally apologize for $\ldots$ & I'm sorry \\
\hline 3 & Excuse me & I'm sorry \\
\hline
\end{tabular}

\section{Example 8 (taken from Monsters University)}

[In the scaring competition, Mike successfully gets maximum point. It makes OK Team become the winner of the competition. Everybody is happy. They get together in the middle of the yard and shout on Mike. They want to congratulate OK Team as the winner]

Sullivan : We're in the scary program. Yeay. [Everybody is happy. They are screaming]

Don Carlton: [Talks to Scoot Squishy Squibbles, a member of OK Team. They are hugging]. You son of a gun. Way to go! [Scoot Squishy Squibbles leaves Don Carlton. Because Don is so happy, he dances and hugs Miss Squibbles accidentally]. Ups, little stuck, pardon me there, Miss Squibbles.

(00:50:32)

This conversation happens after the scaring competition ended. OK Team turns out to be the winner of the competition. Don Carlton comes up to OK Team. He congratulates and hugs Scott Squishy Squibbles. Scott then immediately goes to join his friends to congratulate Mike as the last contestant who does the simulation. Don Carlton 
cannot repress his feeling of happiness. He dances and hugs Scoot's mother, Miss Squibbles, accidentally. Because Don Carlton is very embarrassed and feels guilty, he blushes as he says "Ups, little stuck, pardon me there, Miss Squibbles". He apologizes for accidentally hugging her. Since their relationship is not a close one and limited to teacher and parent relationship, Don Carlton chooses the phrase "pardon me" instead of "I'm sorry". The word "pardon" here is more formal to express an apology.

\section{CONCLUSION}

This study has investigated apologies in four cartoon movies entitled Monsters University, Frozen, Mulan, and Mulan II. The results of this study show that two apology strategies, an expression of an apology (32\%) which is known as a direct apology, and an explanation or account of the situation $(46 \%)$ in which the speaker describes the situation which causes him/her to do the offense, dominate the ranks in which an explanation or account of the situation is the first-highest and an expression of an apology is the second-highest. They are then followed by an acknowledgment of responsibility (11\%) in which the speaker takes responsibility by admitting that the situation is his/her fault, and an offer of repair $(8 \%)$ in which the speaker tries to repair the damage, and a promise of forbearance (3\%) when the speaker commits his/herself to not repeat the mistake.

Concerning the strategy of apology used, a direct expression of regret "sorry" is more often employed by the characters. There are many expressions of regret by saying "sorry" found. It is because such expression is commonly used to apologize. However, the complex direct expressions of apology are obviously followed by explanations.

Besides, the findings of this study also indicate that the utterances of apology are influenced by familiarity. The unfamiliarity between the participants tends to make the speakers use explanation that is more formal than utterances in familiar participants.
In this case, the speakers choose the words such as "pardon", "I d like to formally apologize for ...", and "excuse me". The utterance is quite short but some are also long if they have specific reasons in order to convince the hearer. Meanwhile, if the participants are familiar, they choose the words "I m sorry" or just simply say "sorry".

\section{BIBLIOGRAPHY}

Austin, John. L. How to Do Things with Words. Oxford: Oxford University Press, 1962. Print.

Brown, Penelope \& Levinson, Stephen. C. Politeness: Some Universals in Language Usage. Cambridge: Cambridge University Press, 1978. Print.

Finegan, Edward. Language: Its Structure and Use. 5th ed. Boston: Michael Rosenberg, 2007. Print.

Fraser, Bruce. "On Apologizing." Conversational Routine (1981): 259-271. Print.

Fromkin, Victoria, Robert Rodman, and Nina Hyams. An Introduction to Language. 7th ed. Boston: Michael Rosenberg, 1984. Print.

Handayani, Tutik. "The Analysis of Apologizing Expressions in the Novel Entitled Where Love Was Lost by Marilyn Lynch.” Undergraduate Thesis. Universitas Sebelas Maret, 2010. Print.

Hofstede, Geert. "Cultural Differences in Teaching and Learning." International Journal of Intercultural Relations 10 (1986): 301-320. Print.

Levinson, Stephen. C. Pragmatics. Cambridge: Cambridge University Press, 1983. Print.

Martha, Pratiwi Emmy. “A Socio Pragmatic Analysis of Apology Expressions in English Drama Movie." Undergraduate Thesis. Universitas Muhammadiyah Surakarta, 2010. Print.

Morris, Charles. W. The Pragmatic Movement in American Philosophy. New York: PrenticeHall, 1970. Print. 
Olshtain, Elite. "Apologies." Request and Apologies: A Cross-Cultural Study of Speech Act Realization Patterns (1989): 206-209. Print.

Olshtain, Elite \& Cohen, Andrew D. "Apology: A Speech Act Set." Sociolinguistics and Language Acquisition (1983): 18-35. Print.

Riyani, Ika Dewi. “Apology Strategies Used by the Characters of Joe Wright's Pride and Prejudice Movie." Undergraduate Thesis. Universitas Negeri Islam, 2010. Print.

Sari, Rika Karsitra. "Apology Utterances in Drama Movie.” Undergraduate Thesis. Universitas Gadjah Mada, 2013. Print.

Trosborg, Anna. Interlanguage Pragmatics: Requests, Complaints, and Apologies. Berlin: Gerike GmbH, 1994. Print.

Yule, George. The Study of Language. Cambridge: Cambridge University Press, 2006. Print.

— . Pragmatics. Oxford: Oxford University Press, 1996. Print.

\section{Admission Sheet}

Hereby I state that all statements, opinions, and analysis that I have written in this graduating paper are my original works. It took me about five months to write this graduating paper and during the process I optimally conducted research with the help of some references and my consultant's suggestion. Every word and statement from the references is treated as quotations and excerpts in which the name of the authors and publishers are stated. If any claims related to the analysis that I made persist in the future, I will be fully responsible for clarification.

Devy Putri Larasati 